\title{
Factors of independent of activities of daily living among osteoarthritis elderly
}

\author{
Hariza Adnani ${ }^{1}$, Anna Nur Hikmawati ${ }^{2}$, Siranee Sihapark ${ }^{3}$, Dwi Suharyanta ${ }^{1}$, Dwi Widiyaningsih ${ }^{1}$ \\ ${ }^{1}$ Department of Public Health, Surya Global Institute of Health Science, Yogyakarta, Indonesia \\ ${ }^{2}$ Department of Nursing, Surya Global Institute of Health Science, Yogyakarta, Indonesia \\ ${ }^{3}$ Department of Nursing, Boromarajonani College of Nursing Khon Kaen, Khon Kaen, Thailand
}

\begin{tabular}{l} 
Article Info \\
\hline Article history: \\
Received Jun 12, 2021 \\
Revised Nov 5, 2021 \\
Accepted Nov 15, 2021 \\
\hline Keywords: \\
Activities of daily living \\
Functional abilities \\
Mental status \\
Perception \\
Physiological abilities
\end{tabular}

Physiological abilities

\begin{abstract}
The aim of this cross-sectional study was to determine the relationship between ability to carry out activities of daily living (ADL) independently and functional ability, mental status, exercise habits, and other factors, among elderly people with osteoarthritis (OA) at Pleret Bantul, Indonesia. Measures included Katz Index of Independence in ADL, Western Ontario and McMaster Universities Osteoarthritis Index (WOMAC), and the Short portable mental status questionnaire (SPMSQ). Chi-square analyses odds ratios (OR) were calculated. The study results showed that the ADL independence among the sample was associated with younger age $\mathrm{OR}=.347$; $95 \% \mathrm{CI}=.253-.477)$, exercise habit $\mathrm{OR}=7.07 ; 95 \% \mathrm{CI}=2.86-17.47)$ and functional ability $(\mathrm{OR}=2.34 ; 95 \% \mathrm{CI}=1.82-3.01)$. There was no relationship between living situation or mental status and ADL. These findings can be used as information to design programs to support independence in ADLs among elderly persons with OA in Indonesia.
\end{abstract}

This is an open access article under the CC BY-SA license.

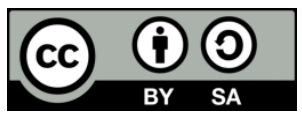

\section{Corresponding Author:}

Hariza Adnani

Public Health Study Program, Institute of Health Science of Surya Global, Yogyakarta

Jl Ringroad selatan Blado, Potorono Banguntapan Bantul Yogyakarta, Indonesia

Email: harizaadnani541@gmail.com

\section{INTRODUCTION}

Indonesia is one of the five countries with the highest number of elderly people in the world reached 18.1 million or $7.6 \%$ of the total population. Based on Central Bureau data in 2013 Statistics project, the number of elderly people (60+) is expected to increase to 27.1 million by 2020, to 33.7 million in 2025 and 48.2 million in 2035. Based on 2013 Base According to Health Research (Riskesdas), the most common diseases suffered by the elderly are non-communicable diseases including hypertension (57.6\%), arthritis (51.9\%), stroke $(46.1 \%)$, dental and oral problems $(19.1 \%)$, chronic obstructive pulmonary disease $(8.6 \%)$ and diabetes mellitus $(4.8 \%)$ [1].

Aging refers to the process of getting older, which occurs during a series of changes over time such as physical, mental and social changes [2]. As shown in many studies, aging leads to a series of problems, with the most concern being the escalating medical expenditures and higher morbidity and mortality [3]. Old age is associated with a gradual decline in physiological reserves, an increased risk of chronic disease, and a general decline in individual capacities [4]. When a person experiences an increase in age, the more likely a person is to experience problems, such as physical, mental, spiritual, economic and social. For the elderly, one of the most basic problems is a health problem because degenerative processes; this is indicated by the data on disease patterns in the elderly. Osteoarthritis (OA) is a leading cause of pain and disability, and leads to a reduced quality of life [5]. 
Most countries are experiencing population ageing, and it is estimated that in 2030 two billion people will be over 60 years old (22\% of the world's population). According to the United Nation's (UN) population estimates, the world's population over 65 will reach two billion in $2050(28 \%)$ in the world [2]. An ageing population is likely to cause increased strain on healthcare systems and increase public expenditures. Thus, it is of interest to maintain good health and high functioning into old age, both for the elderly themselves and for the society as a whole.

According to the World Health Organization (WHO) in 2007, it was known that osteoarthritis suffered by 151 million people worldwide and reached 24 million in the Southeast Asian region. Osteoarthritis (OA) is the most common musculoskeletal disorder that affects patients' quality of life. Approximately 35-40 million Europeans and 355 million people have OA worldwide [6], [7]. According to the American Academy of Orthopedic Surgeon (AAOS), osteoarthritis is one of the five causes of disability due to bone disease [8].

Osteoarthritis (OA), a degenerative disease of the diarthrodial joint, is influenced by mechanical and inflammatory factors with aging, obesity, chronic injury, and secondary disease considered to be the main factors driving the degeneration of articular cartilage [9] OA is also a multifaceted disease based on recent findings that, apart from cellular and molecular mechanisms, inflammation, metabolic processes, and epigenetic modifications [10] are involved in disease pathogenesis and progression [11]-[13].

Osteoarthritis is a chronic disease whose exact cause is not yet known, but it is characterized by a gradual loss of joint cartilage. Based on the National Centers for Health Statistics, an estimated 15.8 million (12\%) adults between the ages of 25-74 years have complaints of osteoarthritis. The prevalence of joint disease in Indonesia is also quite high, up to $24.7 \%$ and it increases with age. The prevalence is $37.2 \%$ at the age of $45-54,45 \%$ at the age of 55-64, 51.9 \% at age of 65-74, and $54.8 \%$ at the age of 75 and more. In the Special Region of Yogyakarta, health workers have found 5.6\% diagnosed for joint disease, 22,7 \% having symptoms and that osteoarthritis is higher in women $(13.4 \%)$ than men $(10.3 \%)$ as well as the symptoms of osteoarthritis in women (27.5\%) higher than men $(21.8 \%)$ [14].

Based on the Statistics of Bantul Regency, one of the Districts in the Special Province of Yogyakarta, Indonesia (2012) the number of elderly residents in Bantul Regency was 111,750 people consisting of 49,892 men and 61,858 women. Life expectancy in Bantul Regency has increased, from 71.31 years in 2010 increased to 71.62 years in 2014 . The problem of the elderly with osteoarthritis was the lack of independence in carrying out activities of daily living. The Observation results show that the elderly who live with children were not independent in carrying out activities of daily life. Likewise, the elderly who do gymnastics do not guarantee their independence in carrying out activities of daily life. Activities of daily living (ADL) refer to activities oriented towards self-care. These activities are fundamental to living in the social world; they enable basic survival and well-being, such as bathing, toileting, dressing and eating [15]. Physical activity among the elderly has been associated with reduced risk from all causes of death and improve physical, mental and social well-being [16]. The benefits of this research are input for the Bantul Pleret Health Center related to the program for the elderly, and for other health centers in Indonesia in increasing the independence of osteoarthritis sufferers in a sustainable manner.

\section{RESEARCH METHOD}

The type of this research was descriptive correlation with cross sectional approach. Respondents in this study were elderly in Bantul Regency, Indonesia. Total sampling and chi square was obtained with 95 samples. The number of samples was determined based on the number of population, asuming that the osteoarthritis elderly were 120 in number. Therefore, this research used the Slovin formula to get $\alpha=0.05$. The sampling technique used was random sampling technique. The inclusion criteria for the elderly in this study are elderly people with osteoarthritis, at least 60 years old, the elderly are residents who live in Pleret District, Bantul Regency, Yogyakarta, Indonesia the elderly are able to understand what the authors say, and the elderly are willing to be respondents. The instrument used to measure independence in the elderly is The Katz Index of Independence in activities of daily living (ADL), Western Ontario and McMaster Universities Osteoarthritis Index (WOMAC) score for functional ability and short portable mental status questionnaire SPMSQ for mental status. The Western Ontario and McMaster Universities Osteoarthritis Index (WOMAC score) which contains 24 questions: five questions about pain, two questions about stiffness and 17 questions about pain activity. This WOMAC score questionnaire uses a score of 1-5. The original measurement scale on this questionnaire uses an ordinal data scale, but it was changed to a nominal scale.

Activities of daily living are a self-care activity that patients must do every day to meet the needs and demands of everyday life. Measurement of the scale of this questionnaire used an ordinal data scale. The mental status questionnaire used a SPMSQ. Bivariate quantitative analysis used the Chi-square test $\left(\boldsymbol{\lambda}^{2}\right)$, is used to discover if there is a relationship between two categorical variables. Two variables should consist of 
two or more categorical, independent groups. Example independent variables that meet this criterion include Functional ability level (total score WOMAC 0-24= light, 24-48=moderate and 48-72=heavy, 72-96=very heavy), physiological ability (gymnastics and non-gymnastics), mental status level (0-2 errors=whole, 3-4 errors=mild impairment, 5-7 errors=moderate impairment and eight or more errors: severe impairment ) [17] and Katz index of independence in Activities of Daily Living (scoring 1=independent, 2-7=dependent). Giving coding in the ADL (Activity of Daily Living) research of the elderly includes: Independent total=1, depending on light $=2$, depending on light $=3$, depending on being $=4$, depending on weight $=5$, depending on the heaviest $=6$ and depending on the total $=7$. The odds ratio $(\mathrm{OR})$ is particularly useful because as an effectsize statistic, it gives clear and direct information. The most influential risk factor was calculated by the odds ratio (OR). The ethical considerations of this study have received approval from the Ethics Committee at the Institute of Health Sciences of Surya Global with number 3.19/KEPK/SSG/IX/2020. This approval is adjusted to the objectives and respondents in this study, namely osteoarthritis in the elderly. The preparation of informed consent was carried out to fulfill the considerations, with the aim of providing accurate information to the osteoarthritis elderly. Furthermore, this consideration has the privilege of being involved in research voluntarily or not.

\section{RESULTS AND DISCUSSION}

\subsection{The characteristic elderly}

The ADL distribution in elderly with osteoarthritis based on individual characteristics in Table 1 shows that in general, the elderly at the aged 60-74 years $(75.8 \%)$, female gender $(77.9 \%)$, and level of education primary school $(50.5 \%)$, employment status was traders $(18.9 \%)$ and employment status was housewife (64.2). The results of other studies indicate that the main factors associated with the onset of knee pain include being female [18]. The prevalence in women is greater than men; OA severity also greater in women. Study shows that hormones play a role in the mechanism of OA [19]. The result of this study was the majority of study elderly low education (primary school). The results of another study showed that low education was predictor factors among dementia among elderly in nursing homes [14]. Overview of respondents by individual can be seen in the Table 1 .

Table 1. The characteristics of respondents

\begin{tabular}{lcc}
\hline \multicolumn{1}{c}{ The characteristics } & $\mathrm{n}$ & $\%$ \\
\hline Age (years) & 72 & 75.8 \\
$60-74$ & 23 & 24.2 \\
$\geq 75$ & & \\
Level of education & 48 & 50.5 \\
Primary school & 42 & 44.2 \\
Junior high school & 3 & 3.2 \\
Senior high School & 2 & 2.1 \\
College & & \\
Gender & 21 & 22.1 \\
Male & 74 & 77.9 \\
Female & & \\
Employment status & 10 & 10.5 \\
Farmer & 18 & 18.9 \\
Traders & 3 & 3.2 \\
Employees & & \\
Non employment status & 3 & 3.2 \\
Retirees & 61 & 64.2 \\
Homemaker & & \\
\hline
\end{tabular}

\subsection{Bivariate analysis}

The ADL distribution in elderly with osteoarthritis based on variable research in Table 2 shows that in general, the elderly were 60-74 years (75.8\%), live with child and other people (family/others) each 34.7, and have moderate functional ability (87.4), non-gymnastic physiological ability (52.6), whole cognitive ability (47.4).

The results of the bivariate analysis that showed the relation among variables affecting the independence of the ADL of the elderly are shown in Table 2. The results show that there was correlation between age in the elderly and ADL independence. It was seen from the value of Pearson Chi square $(\lambda 2)$ and asymp significant ( $\mathrm{p}$-value). There was correlation between physiological ability and the independence of the elderly in fulfilling ADL. Physiological ability had a risk of OR=7.07 (95\% CI=2.86-17.47) increasing the independence of the elderly in fulfilling ADL. In addition, there was correlation between functional ability and the independence of the elderly in fulfilling ADL functional ability whose risk was OR=2.34 $(95 \%$ 
$\mathrm{CI}=1.82-3.01$ ) increases the independence of the elderly in fulfilling ADL. It was also found that age was the protective factor for the independence of the elderly in fulfilling ADL with $\mathrm{OR}=.347$ (95\% CI=.253-.477). Besides, there was no correlation between place and ADL and also between cognitive ability and the independence of the elderly in fulfilling ADL.

Tabel 2. The distribution of relationships between variables influencing the independence of the elderly's activities of daily living (ADL) of the elderly

\begin{tabular}{|c|c|c|c|c|c|c|c|c|c|}
\hline & \multicolumn{4}{|c|}{ ADL } & \multirow{3}{*}{$\mathrm{n}=95$} & \multirow{3}{*}{$\lambda^{2}$} & \multirow{3}{*}{ OR } & \multirow{3}{*}{$95 \% \mathrm{CI}$} & \multirow{3}{*}{$\mathrm{p}$} \\
\hline & \multicolumn{2}{|c|}{ independent } & \multicolumn{2}{|c|}{ Non independent } & & & & & \\
\hline & $\mathrm{n}$ & $\%$ & $\mathrm{n}$ & $\%$ & & & & & \\
\hline \multicolumn{10}{|l|}{ Age (years) } \\
\hline $60-74$ & 47 & 49.5 & 25 & 26.3 & $72(75.8)$ & 29.7 & .347 & $.253-.477$ & .000 \\
\hline$\geq 75$ & 0 & 0 & 23 & 24.2 & $23(24.2)$ & & & & \\
\hline \multicolumn{10}{|l|}{ Place } \\
\hline Living alone & 2 & 2.1 & 7 & 7.4 & $9(9.5)$ & 7.07 & 1.76 & $.532-5.84$ & .349 \\
\hline With child & 4 & 4.2 & 29 & 30.5 & $33(34.7)$ & & & & \\
\hline With a patner & 2 & 2.1 & 18 & 18.9 & $20(21.1)$ & & & & \\
\hline Others & 2 & 2.1 & 31 & 32.6 & $33(34.7)$ & & & & \\
\hline \multicolumn{10}{|l|}{ Functional ability } \\
\hline Light & 0 & 0 & 9 & 9.5 & $9(9.5)$ & 14.7 & 2.34 & $1.82-3.01$ & .000 \\
\hline Moderat & 10 & 10 & 73 & 76.8 & $83(87.4)$ & & & & \\
\hline Heavy & 0 & 0 & 3 & 3.1 & $3(3.1)$ & & & & \\
\hline \multicolumn{10}{|l|}{ Physological ability } \\
\hline Gymnastics & 33 & 70.5 & 12 & 12.6 & $45(47.4)$ & 19.5 & 7.07 & $2.86-17.47$ & .000 \\
\hline Non gymnastics & 14 & 14.7 & 36 & 37.9 & $50(52.6)$ & & & & \\
\hline \multicolumn{10}{|l|}{ Mental status } \\
\hline Whole & 5 & 5.3 & 40 & 42.1 & $45(47.4)$ & .843 & 1.46 & $.650-3.284$ & .358 \\
\hline Mild impairment & 3 & 3.2 & 27 & 28.4 & $30(31.6)$ & & & & \\
\hline Moderate impairment & 2 & 2.1 & 16 & 16.8 & $18(18.9)$ & & & & \\
\hline Severe impairment & 0 & 0 & 2 & 2.1 & $2(2.1)$ & & & & \\
\hline
\end{tabular}

The results of this study indicate that the majority of elderly who have osteoarthritis were female and aged 60-74 years. There was consistent evidence that females were at higher risk of knee OA.(pooled OR 1.68, 95\% CI 1.37- 2.07) [20]. The results of another study showed that Knee and hip OA rates increased continuously with age and female-to-male rate ratios (RRs) were highest at age 70-75years [21]. This is supported by research, showing that more elderly people aged $\geq 60$ are at risk for osteoarthritis. Increasing age in a person will cause a reduction in volume/contents of cartilage, proteoglycans, cartilage vascularity and perfusion, decreased muscle strength, loss of proprioception, degenerative changes in the meniscus and ligament joints, and calcification of joint tissue [22]. This change can cause the joint space to narrow, causing friction between the ends of the bones in the knee, this is what causes pain [23]. In contrast, the risk of female hand OA peaks at age 60-64 years, and the corresponding female-to-male rate ratios (RRs) were highest at 50-55 years [21]. Age is the biggest risk factor for asteoarthritis strong. Mechanism is still unclear, but it is closely related to the process biology of the joints. The aging process will decrease the number of chondrocytes in cartilage send and will correlate directly with the degree of cartilage damage [19].

The result of this study was that the majority of the elderly have the role of family members and still live with their families, both with their spouses, children, and child-in-laws [24]. There is no relationship between places with ADL. This is in line with the results of other studies which state family support, mental status and ADL as determinants of non-communicable diseases in the elderly [25].

The result of statistical tests of functional ability and ADL independence level showed that there was a significant relationship between functional ability and ADL level of the elderly with osteoarthritis in Bantul, Indonesia. If the functional ability of the elderly is getting better, the level of independence of the elderly ADL will also be better or independent. Research conducted, showed that the majority of elderly people suffering from chronic diseases one of which is osteoarthritis; it causes a decrease in functional status, as well as exposure to various risk factors and life experiences that greatly affect the mental status of the elderly so as to make the elderly more prone to depression [26]. Based on several theories, there are several clinical manifestations of osteoarthritis, namely pain, stiffness, swelling, limited mobility, crepitus, and deformities, and some of these can lead to decreased functional abilities and depression. Decreased functional ability can be caused by joint stiffness, joint swelling, and limited joint motion, while the degree of independence of ADL in the elderly can occur because someone who experiences chronic pain will experience feelings of hopelessness and depression associated with changes in daily activities [27], [28].

Int J Public Health Sci, Vol. 11, No. 1, March 2022: 1-7 
The result of statistical tests of physological ability and ADL independence level showed that there was a significant relationship between physical activity and ADL level of the elderly with osteoarthritis in Pleret Bantul, Indonesia. Physological ability habits create the greatest risk of OA which means that those with more varied exercise routines have a lower risk of developing knee OA [29]. Exercise and physical activity are highly recommended to reduce pain and improve joint function. Strengthening the quadriceps and hamstring muscles is important because it can strengthen the muscles around the knee joint, so that it can find the knee joint [30], [31]. There is no relationship between mental statuses with ADL. This is in line with the results of other studies which state that family support, mental status and ADL are determinants of noncommunicable diseases, not ADL.

\section{CONCLUSION}

The degree of ADL in elderly with osteoarthritis is influenced by age, physiological ability and functional ability. In addition, the dominant risk factor is physiological ability. The degree of ADL in elderly people with osteoarthritis is influenced by age, physiological abilities and functional abilities. In addition, the dominant risk factor is physiological ability. Health services can use the results of this study as a source of data on problems with functional abilities, physiological abilities and levels of ADL independence that occur in the elderly. This can be an input in increasing special programs to reduce the level of dependence of the elderly (independent elderly) and increase functional abilities. Health services should maximize health education so that public knowledge of determine the risk factors of activities of daily living (ADL) independent in osteoarthritis elderly can be increased.

\section{ACKNOWLEDGEMENTS}

The authors acknowledge to the Institute of Health Sciences of Surya Global Yogyakarta (STIKES Surya Global Yogyakarta) and Boromarajonani College of Nursing Khon Kaen (BCNKK) for supporting this research.

\section{REFERENCES}

[1] J. Yunita, N. Nurlisis, and W. Sari, "Determinants of the quality of life among pre-elderly and elderly population," International Journal of Public Health Science (IJPHS), vol. 8, no. 3, pp. 341-345, Sep. 2019, doi: 10.11591/ijphs.v8i3.20246.

[2] K. Yavari, M. Basakha, H. Sadeghi, and A. Naseri, "Economic Aspects of Ageing," Iranian Journal of Ageing, vol. 10, no. 1, pp. 92-105, 2015

[3] M. C. S. Wong, D. X. Zhang, and H. H. X. Wang, "Rapid emergence of atherosclerosis in Asia: A systematic review of coronary atherosclerotic heart disease epidemiology and implications for prevention and control strategies," Current Opinion in Lipidology, vol. 26, no. 4, pp. 257-269, Aug. 2015, doi: 10.1097/MOL.0000000000000191.

[4] C. J. Steves, T. D. Spector, and S. H. D. Jackson, "Ageing, genes, environment and epigenetics: what twin studies tell us now, and in the future," Age and Ageing, vol. 41, no. 5, pp. 581-586, Sep. 2012, doi: 10.1093/ageing/afs097.

[5] V. Silverwood, M. Blagojevic-Bucknall, C. Jinks, J. L. Jordan, J. Protheroe, and K. P. Jordan, "Current evidence on risk factors for knee osteoarthritis in older adults: a systematic review and meta-analysis," Osteoarthritis and Cartilage, vol. 23, no. 4, pp. 507-515, Apr. 2015, doi: 10.1016/j.joca.2014.11.019

[6] F. Barry and M. Murphy, "Mesenchymal stem cells in joint disease and repair," Nature Reviews Rheumatology, vol. 9, no. 10, pp. 584-594, Oct. 2013, doi: 10.1038/nrrheum.2013.109.

[7] A. Mobasheri, "The future of osteoarthritis therapeutics: Targeted pharmacological therapy topical collection on osteoarthritis," Current Rheumatology Reports, vol. 15, no. 10, pp. 1-13, Oct. 2013, doi: 10.1007/s11926-013-0364-9.

[8] D. S. Jevsevar, "Treatment of Osteoarthritis of the knee: Evidence-based guideline, 2nd Edition," Journal of the American Academy of Orthopaedic Surgeons, vol. 21, no. 9, pp. 571-576, Sep. 2013, doi: 10.5435/00124635-201309020-00008

[9] S. Raman, U. FitzGerald, and J. M. Murphy, "Interplay of inflammatory mediators with epigenetics and cartilage modifications in osteoarthritis," Frontiers in Bioengineering and Biotechnology, vol. 6, Mar. 2018, doi: 10.3389/fbioe.2018.00022.

[10] J. Shen, Y. Abu-Amer, R. J. O'Keefe, and A. McAlinden, "Inflammation and epigenetic regulation in osteoarthritis," Connective Tissue Research, vol. 58, no. 1, pp. 49-63, Jan. 2017, doi: 10.1080/03008207.2016.1208655

[11] F. J. Blanco and I. Rego-Pérez, "Editorial: is it time for epigenetics in osteoarthritis?," Arthritis \& Rheumatology, vol. 66, no. 9, pp. 2324-2327, Sep. 2014, doi: 10.1002/art.38710

[12] M. Ishijima, H. Kaneko, and K. Kaneko, "The evolving role of biomarkers for osteoarthritis," Therapeutic Advances in Musculoskeletal Disease, vol. 6, no. 4, pp. 144-153, Aug. 2014, doi: 10.1177/1759720X14541175.

[13] A. Courties, O. Gualillo, F. Berenbaum, and J. Sellam, "Metabolic stress-induced joint inflammation and osteoarthritis," Osteoarthritis and Cartilage, vol. 23, no. 11, pp. 1955-1965, Nov. 2015, doi: 10.1016/j.joca.2015.05.016.

[14] S. Nugraha and Y. T. Aprillia, "Health-related quality of life among the elderly living in the community and nursing home," Jurnal Kesehatan Masyarakat, vol. 15, no. 3, pp. 419-425, Mar. 2020, doi: 10.15294/kemas.v15i3.21282.

[15] D. A. Amini et al., "Occupational therapy practice framework: Domain \& process 3rd edition," American Journal of Occupational Therapy, vol. 68, no. Supplement_1, pp. S1-S48, Mar. 2014, doi: 10.5014/ajot.2014.682006.

[16] M. F. Bin Saad, C. W. Lian, and H. Hazmi, "Socio-demography, nutritional status and physical activity among elderly in Samarahan division, Sarawak, Malaysia," International Journal of Public Health Science (IJPHS), vol. 10, no. 2, pp. 311-317, Jun. 2021, doi: 10.11591/ijphs.v10i2.20739.

[17] E. Pfeiffer, "A short portable mental status questionnaire for the assessment of organic brain deficit in elderly patients $\dagger$," Journal of the American Geriatrics Society, vol. 23, no. 10, pp. 433-441, Oct. 1975, doi: 10.1111/j.1532-5415.1975.tb00927.x.

[18] G. Musumeci, F. C. Aiello, M. A. Szychlinska, M. Di Rosa, P. Castrogiovanni, and A. Mobasheri, "Osteoarthritis in the XXIst 
century: risk factors and behaviours that influence disease onset and progression," International Journal of Molecular Sciences, vol. 16, no. 3, pp. 6093-6112, Mar. 2015, doi: 10.3390/ijms16036093.

[19] W. Zhang et al., "Nottingham knee osteoarthritis risk prediction models," Annals of the Rheumatic Diseases, vol. 70, no. 9, pp. 1599-1604, Sep. 2011, doi: 10.1136/ard.2011.149807.

[20] D. Prieto-Alhambra, A. Judge, M. K. Javaid, C. Cooper, A. Diez-Perez, and N. K. Arden, "Incidence and risk factors for clinically diagnosed knee, hip and hand osteoarthritis: influences of age, gender and osteoarthritis affecting other joints," Annals of the Rheumatic Diseases, vol. 73, no. 9, pp. 1659-1664, Sep. 2014, doi: 10.1136/annrheumdis-2013-203355.

[21] A. Ismail, C. Moore, N. Alshishani, K. Yaseen, and M. A. Alshehri, "Cognitive behavioural therapy and pain coping skills training for osteoarthritis knee pain management: a systematic review," Journal of Physical Therapy Science, vol. 29, no. 12, pp. 2228-2235, 2017, doi: 10.1589/jpts.29.2228.

[22] T. T. Marlina, "The effectiveness of knee exercises on reducing pain intensity in knee osteoarthritis patients in Yogyakartan," Jurnal Keperawatan Sriwijaya, vol. 2, no. 1, pp. 44-56, Nov. 2015.

[23] Chandra Kusuma, "The correlation of degrees of knee osteoarthritis according to kellgren and lawrence with the timed up and go (TUG) test in knee osteoarthritis patients at the orthopedic surgery clinic, RSU dr. Soedarso Pontianak," Jurnal Mahasiswa PSPD FK Universitas Tanjungpura, vol. 1, no. 1, Apr. 2014.

[24] X. Huang et al., "The association between physical activity, mental status, and social and family support with five major noncommunicable chronic diseases among elderly people: a cross-sectional study of a rural population in southern china," International Journal of Environmental Research and Public Health, vol. 12, no. 10, pp. 13209-13223, Oct. 2015, doi: 10.3390/ijerph121013209.

[25] S. Puspita, E. R. K. Waty, and A. Husin, "Community participation in following posyandu mawar activities in Indralaya Ogan Ilir District," Jurnal Pendidikan dan Pemberdayaan Masyarakat, vol. 5, no. 2, pp. 54-65, Mar. 2018, doi: 10.36706/jppm.v5i2.8282.

[26] H. P. Kuntoro and P. Yuniarto, General pain and knee osteoarthritis from a physiotherapeutic aspect. Surakarta: Muhammadiyah University Press, 2011.

[27] S. Suriani and S. I. Lesmana, "Theraband exercises are better at lowering pain than quadricep bench exercises in osteoarthritis genu," Fisioterapi : Jurnal Ilmiah Fisioterapi, vol. 13, no. 1, p. 46, 2013.

[28] D. T. Felson et al., "Risk factors for incident radiographic knee osteoarthritis in the elderly. The framingham study," Arthritis \& Rheumatism, vol. 40, no. 4, pp. 728-733, 1997, doi: 10.1002/art.1780400420.

[29] A. H. Al-Johani et al., "Comparative study of hamstring and quadriceps strengthening treatments in the management of knee osteoarthritis," Journal of Physical Therapy Science, vol. 26, no. 6, pp. 817-820, 2014, doi: 10.1589/jpts.26.817.

[30] S. Anwer and A. Alghadir, "Effect of isometric quadriceps exercise on muscle strength, pain, and function in patients with knee osteoarthritis: a randomized controlled study," Journal of Physical Therapy Science, vol. 26, no. 5, pp. 745-748, 2014, doi: 10.1589/jpts.26.745.

[31] B. Q. Jones, C. Covey, and J. Marvin Sineath, "Nonsurgical Management of knee pain in adults," American Family Physician, vol. 92 , no. 10 , pp. $875-883$, Nov. 2015.

\section{BIOGRAPHIES OF AUTHORS}

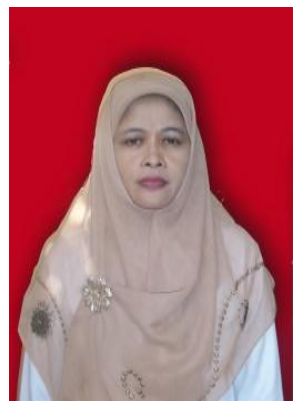

Hariza Adnani (ID 81 SC P is a lecturer in Epidemiology and Public Health Study Program at Sekolah Tinggi Ilmu Kesehatan Surya Global Jogjakarta (Surya Global Institute of Health Science). Several textbooks and monographs have been produced with title: Introduction to Epidemiology, Public Health Sciences and Geographic Information Systems for Environmentally Based Diseases (monographs). Several studies have been published in national and international journals related to epidemiology and health promotion entitled: Risk factor Mapping and Case Map of Environmentally Based Disease in Yogyakarta (Medical Journal of Indonesia-Scopus Q4), Perception Factor, Intention and Attitude with Market Community Participation to Prevent Occupational Diseases (International Journal of public Health Science-Sinta 2) and Health Promotion in Clean and Healthy Behavior Program in Traditional Markets (International Research Journal of Management, IT \& Social Science). She can be contacted at email: harizaadnani541@gmail.com

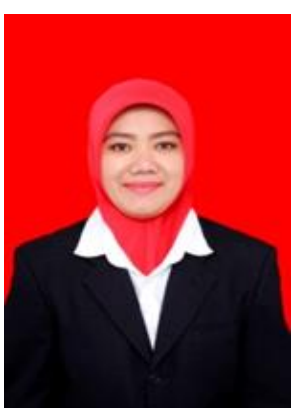

Anna Nur Hikmawati (D) SC SC $\mathrm{P}$ is a nursing lecturer at Sekolah Tinggi Ilmu Kesehatan Surya Global Jogjakarta (Surya Global Institute of Health Science). The fields of her knowledge are on family nursing and nursing management courses. Her educational background includes Master's Degree in Nursing at University of Muhammadiyah Yogyakarta. Her several articles that have been published in accredited National Journals, including the 2020 article with title "Family Phenomenology Studies as A Supervisor For Swallowing Drugs In TB Patients on Adherence to Treatment For TB Patients", in 2021 an article with title "The Effect of Health Education with Audiovisual Methods on Family Support For TB Patients" and article with title "Relationship Between Workload and Nurse's Work Stress". She also has proceedings with title "Perception Of Body Image With Personal Hygiene For The Elderly at BPSTW Unit Budi Luhur Kasongan Bantul Yogyakarta" and she has several certified copyrights modules, pocket books and posters. She can be contacted at email: annahikmawati24@gmail.com. 

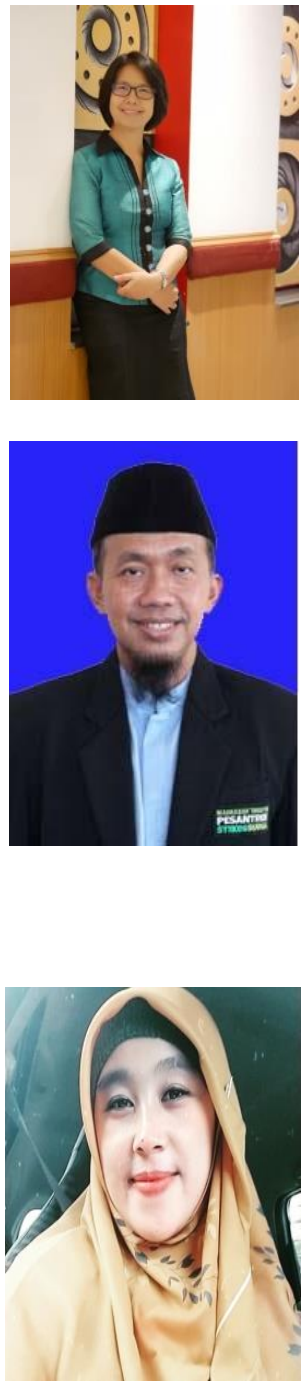

Siranee Sihapark (D) SC SC is a nurse lecturer and researcher at Boromarajonani college of nursing Khon Kean Thailand. Her educational background includes Ph.D. (Community Health Development), Master's Degree of Nursing (Community Nursing) and Advanced Practice Nurses (Community Nursing). Her work experience includes the following: elderly care in community, long term care, senior citizens Club, and health promotion networks in the elderly in community. Her published works such as; 1 . Severe Disability Among Elderly Community Dwellers in Rural Thailand: Prevalence and Associated Factors, 2. Implementation Science in Thailand: Design and Methods of a geriatric Mental Health Cluster - Randomized Trail, and 3. Citizens'Jury and Elder Care: Public Participation and Deliberation in Long-Term Care Policy in Thailand. She can be contacted at email: siranee.s@bcnkk.ac.th

Dwi Suharyanta (iD 8. SC P is the Director of Sekolah Tinggi Ilmu Kesehatan Surya Global Jogjakarta (Surya Global Institute of Health Science) and holding position from 2019 to 2024. $\mathrm{He}$ is also a lecturer in the Public Health Study Program by teaching Hospital Management Courses. His educational background including Bachelor Degree at the National Development University "Veteran" (Universitas Pembangunan Nasional "Veteran") Jogjakarta in engineering, postgraduate program at Artha Budhi Aswara Institute of Economic in Surabaya for his Master of Management (MM). In 2007 he graduated from Universitas Gadjah Mada for his Master in Health (M. Kes). In 2018 he published research with title "The Role of Parents of Health Workers and Peers in Preventing Smoking Behavior in Adolescents" in journal of health management, STIKES RS DR. Soetomo Surabaya. In 2020 he also did publication with title "Socio-cultural and Geographical Influence on Smoking Behavior in Elderly Women in the Dieng Wonosobo Highlands Area" and published in health management journal, STIKES RS DR Soetomo Surabaya. He also wrote a book with title "Health promotion and Advocacy" published by deepublish. He can be contacted at email: dwisuharyanta@gmail.com

Dwi Widiyaningsih (iD $8 \mathrm{SC}$. $\mathrm{P}$ is a lecturer in the PublicHealth Study Program by teaching Health Promotion Courses. She is also a staff in research and community service program at Sekolah Tinggi Ilmu Kesehatan Surya Global Jogjakarta. Her educational background including Bachelor Degree in Public Health at Sekolah Tinggi Ilmu Kesehatan Surya Global Yogyakarta and her Master's Degree in the same field at Sebelas Maret University. In 2018 she has been published an article with title "The Role of Parents of Health Workers and Peers in Preventing Smoking Behavior in Adolescents" in journal of health management, STIKES RS DR. Soetomo Surabaya. In 2019 she published her research with tittle "Assistance Planning and Implementation of a Clean and Healthy Living Behavior Program (PHBS) Household Order in Bantul Yogyakarta" in Humanism Journal of Community Empowerment. In 2020 she published an article with title "Socio-cultural and Geographical Influence on Smoking Behavior in Elderly Women in Dieng Wonosobo Highlands Area" in the journal of health management, STIKES RS DR. Soetomo. In the same periode she was also published research with title "Non-Pharmacological Therapy Grade Smoking Counseling on Women's Smoking in The Dieng Highlands Area" and published in the Journal of Healthy Community Service. As a lecturer she has been written a book with title "Health Promotion and Advocacy" and second book with title "Health Promotion Basic Textbook "it all published by deepublish. In 2021 she has publication at the same journal of health management, STIKES RS DR. Soetomo with Title "The Role of Health Personnel and Family Support to Control of Smoking Behavior in Elderly Women in The Dieng Highlands Area." She can be contacted at email: widiya23juni@gmail.com. 